\title{
Effects of Climate Change and Natural Disasters on Cattle Farming in Selected Areas of Bangladesh: A Preliminary Investigation
}

\author{
Md. Ruhul Amin ${ }^{1, ~ *, ~ S . ~ M . ~ J a h a n g i r ~ H o s s a i n ~}{ }^{1,2}$, Md. Ahsanul Kabir², Md. Faizul Hossain Miraz², \\ Md. Shahin Alam ${ }^{3}$, Subrata Sarker ${ }^{4}$ \\ ${ }^{1}$ Red Chittagong Cattle Improvement Project (Phase-2), Bangladesh Livestock Research Institute, Dhaka, Bangladesh \\ ${ }^{2}$ Biotechnology Division, Bangladesh Livestock Research Institute, Dhaka, Bangladesh \\ ${ }^{3}$ Department of Dairy and Poultry Science, Hajee Mohammad Danesh Science and Technology University, Dinajpur, Bangladesh \\ ${ }^{4}$ Department of Livestock Services, Ministry of Fisheries and Livestock, Dhaka, Bangladesh
}

Email address:

ruhulaminbau@yahoo.com (Md. R. Amin)

${ }^{*}$ Corresponding author

\section{To cite this article:}

Md. Ruhul Amin, S. M. Jahangir Hossain, Md. Ahsanul Kabir, Md. Faizul Hossain Miraz, Md. Shahin Alam, Subrata Sarker. Effects of Climate Change and Natural Disasters on Cattle Farming in Selected Areas of Bangladesh: A Preliminary Investigation. American Journal of Environmental and Resource Economics. Vol. 6, No. 1, 2021, pp. 23-28. doi: 10.11648/j.ajere.20210601.14

Received: February 25, 2021; Accepted: March 15, 2021; Published: March 26, 2021

\begin{abstract}
Climate change and natural disasters have unequivocal impacts on global agricultural production systems thereby its threats hampering food production and security. The current study was undertaken to identify the natural disasters affecting cattle farming along with the strength of the ability of the farmers to tackle cattle against natural disaster and knowledge and feelings on the impact of climate change in the Bangladesh perspective. A total of 719 cattle rearing households were surveyed from selected 14 upazilas of 9 districts. Data were analyzed with SPSS 20.0 software using descriptive statistics. From the study, it was found that most of the households (95.13\%) were farm households depending on agricultural activities. The average herd sizes of indigenous, Red Chittagong Cattle (RCC) and crossbred cattle were $3.84,2.67$, and 7.64 respectively. The average number of bull calf/bull in the case of indigenous (2.22) and RCC (2.43) were higher indicating that farmers were mainly reared these genotypes of cattle for fattening purpose and in the case of crossbred the average number of the milch cow was higher (3.04) indicating farmers rearing crossbred cattle mainly for dairy purpose. However, irrespective of areas $52.97 \%$ of cattle rearing farmers thought that natural disaster affected their cattle rearing and the highest $62.08 \%$ of farmers thought that the cattle rearing affected by flood followed by cyclone $(57.83 \%)$, heavy rainfall $(54.00 \%)$, thunderstorm $(44.79 \%)$, drought $(24.07 \%)$ and river erosion $(9.66 \%)$. Moreover, overall $43.71 \%$ of cattle farmers and the highest $88.89 \%$ cattle farmers in Sylhet district reported that they were unable to tackle cattle against natural disasters. Furthermore, overall $12.95 \%$ of cattle farmers found they were ignorant about the climate change issues. The farmers in Bandarban (100.00\%), Tangail (66.67\%), Jessore (94.87\%), and Rajshahi (76.19\%) districts were had knowledge and feeling, on the other hand in Kurigram (97.83\%) and Mymensingh $(45.45 \%)$ districts farmers had no knowledge and feeling over climate change issues. Cattle farmers assumed that cattle health $(64.22 \%)$ and production performance $(49.09 \%)$ were mostly affected by climate change issues. Climate change effect and increasing weather extremes, directly and indirectly affects cattle rearing, thus impose bigger consequences to the livestock economy, alongside national food security. There has been no direct study conducted on the effects of climate change on cattle rearing in Bangladesh. This study affords to explore the effects of climate change and natural disasters on cattle rearing and provides preliminary guidelines to policymakers and for further research in the Bangladesh perspective.
\end{abstract}

Keywords: Natural Disasters, Climate Change, Cattle Rearing, Effects, Farmers’ Knowledge 


\section{Introduction}

Bangladesh is recognized as extremely vulnerable to climate change and the most disaster-prone country in the world. The natural disaster includes floods, droughts, seasonal storm, heavy rainfall, riverbank erosion, landslides, cyclone; earthquakes are the major cause of most direct and indirect damage in the country [1]. Bangladesh is ranked $8^{\text {th }}$ as a high-risk country for suffering extreme weather conditions due to climate change [2]. The Intergovernmental Panel on Climate Change (IPCC) [3] highlighted that due to climate change drought, floods, cyclones, and extreme temperature conditions will severely affect agriculture in developing countries. Due to climate change, storms and drought are more severe and more frequent, resulting in changes in timing and changes in the pattern of seasonal cyclones, seasonal diversity, and quantity of rainfall which affecting agricultural production [1]. Salinity in the coastal areas, storms, drought, irregular rainfall, high temperature, flash floods resulted from climate change that is, directly and indirectly, affecting crop production [4].

In Bangladesh, temperature and precipitation patterns have great importance as it has an agro-based economy. Bangladesh has made significant achievements in increasing incomes and reducing poverty over the last 20 years which are threatened by climate change. The yearly average maximum temperature of the country has been increasing at a rate of $0.018^{\circ} \mathrm{C}$ per year and a significant increase during the 33 years was observed in the South Eastern region $\left(1.287^{\circ} \mathrm{C}\right)$ and minimum at Central region $\left(0.11^{\circ} \mathrm{C}\right)$ [5]. In another study forecasted that the temperature of the country will increase in the range of $1.81-2.04^{\circ} \mathrm{C}$ by $2021-2060$ and $3.68-4.47^{\circ} \mathrm{C}$ by 2061-2100 periods. In the case of rainfall, it is observed that rainfall levels will be decreased by $4.80 \%$ by $2021-2060$ and $5.47 \%$ by $2061-2100$ periods [6]. In the South Asian region increased summer precipitation, therefore increase in flashflood is the major risk from the climate change. It was also found that due to climate change the arid and semi-arid regions would be drier in the summer season which could cause severe droughts in the South Asian region [7]. However, temperature increase leads to a rise in the sea level, and due to high soil and water salinity, the coastal belt of Bangladesh is at an extreme risk $[8,9]$. Natural disasters and climate change have human and non-human effects and adversely affecting the functioning of the ecosystem, agriculture and food security, infrastructure, water resources, and human health [10]. Climate change is now therefore, recognized as one of the most serious challenges facing the world, its people, the environment, and its economies for this reason low employment opportunity in the marginal areas, where the majority of the population depend on livestock for their livelihoods [11]. The effects of climate change on livestock production and health an additional significant burden to livestock development [12]. Climate variability has effects on the livelihoods of livestock farmers and they are at risk of food, economic security, and cultural preservation
[13]. The previous study revealed that water scarcity, shortage of pasture land, and disease dynamics due to the impact of climate change create problems in the production of livestock. Increased diseases in livestock have adverse effects on livestock farmers, marketability, animal health, and livelihoods of farmers [14]. However, salinization in water and soil is hampering crop and livestock production [8]. A few researches have been conducted on the effects of climate change on livestock and more specifically on cattle rearing in Bangladesh. Considering the fact the research aims to identify the natural disasters that often affect cattle farming along with strength of the ability of the farmers to tackle cattle against natural disaster and knowledge and feelings of cattle farmers about the impact of climate change in the Bangladesh perspective.

\section{Methodology}

\subsection{Documents Review}

Study on the relevant document was done before the time of inception of this research which information, later on, was used for the development of detailed methodology, work planning, and questionnaire formation, data collection, and analysis.

\subsection{Selection of the Study Areas}

Total 14 upazilas of 9 districts (Chattagram, Sylhet, Jeshore, Mymensingh, Banderban, Shariatpur, Rajshahi, Kurigram, and Tangail) were selected for the study. The areas were selected in such a way that the result would be more inclusive and representative of the entire country. The hilly, plain land and riverbank areas were covered and all climatic zones were tried to include in the study areas.

\subsection{Development of Questionnaires}

The questionnaire was developed based on the objectives of the research and which was fulfilled the scope of the study. Both quantitative and qualitative approach was used in the questionnaire. However, open questions were used for acquiring qualitative information and for determining people's opinions, knowledge and feelings.

\subsection{The Sample Size for the Household Survey}

Considering budget, manpower, and time the number of samples for the household survey was fixed as 50 for each of the upazila. But actually, a total of 719 households were surveyed to collect quantitative and qualitative data for the study.

\subsection{Methods of Data Collection}

The household survey was performed by a group of trained enumerators appointed in those areas. The enumerators visited the areas and collected data on-farm by interviewing farmers face to face. 


\subsection{Data Analysis}

After intensive processing and synthesizing the collected data inputted to MS Excel. Then data were analyzed using descriptive statistics with SPSS 20.0 software.

\section{Results and Discussions}

\subsection{Types of the Households}

Table 1. Types of the households in the study areas.

\begin{tabular}{lll}
\hline District & Farm households & Non-farm households \\
\hline Bandarban & $100.00 \%$ & - \\
Chattogram & $89.73 \%$ & $10.27 \%$ \\
Jessore & $100.00 \%$ & - \\
Kurigram & $100.00 \%$ & - \\
Mymensingh & $98.36 \%$ & $1.64 \%$ \\
Rajshahi & $98.15 \%$ & $1.85 \%$ \\
Shariatpur & $96.15 \%$ & $3.85 \%$ \\
Sylhet & $98.04 \%$ & $1.96 \%$ \\
Tangail & $100.00 \%$ & - \\
Overall & $95.13 \%$ & $4.87 \%$ \\
\hline
\end{tabular}

Table 1 shows the types of cattle rearing households surveyed irrespective of the study areas. Most of the households $(95.13 \%)$ were farm households depending on agricultural activities. All the households (100.00\%) were farm households found in Bandarban, Jessore, Kurigram, and Tangail districts. However, the non-farm households were found $4.87 \%$ and the highest (10.27\%) non-farm households were found in the Chattogram district. Previous study reported that in Bangladesh $63.11 \%$ are farm and $36.89 \%$ are non-farm households [15] which differs from the present finding because mainly cattle rearing households were surveyed for the present study.

\subsection{Cattle Population Structures of Different Genotypes of Cattle}

The study revealed that the average herd size of indigenous cattle was 3.84 (Table 2) and the maximum number of indigenous cattle reared by farmers were found 30 irrespective of the study areas. The herd size of indigenous cattle was 4.19 reported by the previous study which is agreed to the present study [16]. In the case of crossbred cattle herd size was 7.64 and the maximum number of cattle was 29 . The average number of the milch cow was found highest and the value was 3.04 in the case of crossbred cattle. In the previous finding, the average number of milch cow was found 1.94 for crossbred cattle [17] which disagreed with the current findings may be for only smallholder farmers were considered for that study. However, in the case of RCC herd size was 2.67 and the maximum number of RCC was found 9 in the study areas. The average number of bull calf/bull was found the highest (2.43) followed by heifer (1.38) in the case of RCC. The average number of bull calf/bull in the case of indigenous (2.22) and RCC (2.43) were higher indicating that farmers were mainly reared these genotypes of cattle for fattening purpose and in the case of crossbred the average number of the milch cow was higher (3.04) indicating farmers rearing crossbred cattle mainly for dairy purpose.

Table 2. Cattle population structures based on different genotypes of cattle.

\begin{tabular}{|c|c|c|c|c|c|c|c|c|c|}
\hline \multirow{2}{*}{ Types of cattle } & \multicolumn{3}{|c|}{ Indigenous } & \multicolumn{3}{|c|}{ Crossbred } & \multicolumn{3}{|l|}{ RCC } \\
\hline & Min & Max & Average & Min & Max & Average & Min & Max & Average \\
\hline Milch cow & 1 & 8 & $1.54(256)$ & 1 & 12 & $3.04(167)$ & 1 & 5 & $1.27(59)$ \\
\hline Dry cow & 1 & 3 & $1.60(81)$ & 1 & 5 & $1.66(106)$ & 1 & 2 & $1.27(11)$ \\
\hline Pregnant cow & 1 & 6 & $1.56(103)$ & 1 & 5 & $1.84(112)$ & 1 & 2 & $1.10(21)$ \\
\hline Suckling heifer & 1 & 8 & $1.42(185)$ & 1 & 5 & $2.30(132)$ & 1 & 3 & $1.22(27)$ \\
\hline Weaned heifer $(<2$ years) & 1 & 4 & $1.36(36)$ & 1 & 5 & $1.81(26)$ & 1 & 3 & $1.24(17)$ \\
\hline Heifer (>2yrs) & 1 & 6 & $1.56(48)$ & 1 & 4 & $1.54(26)$ & 1 & 3 & $1.38(08)$ \\
\hline Weaned bull calf $(<2$ years $)$ & 1 & 8 & $1.89(44)$ & 1 & 8 & $1.89(18)$ & 1 & 2 & $1.13(16)$ \\
\hline Bull calf/bull (>2years) & 1 & 9 & $2.22(152)$ & 1 & 15 & $2.51(61)$ & 1 & 9 & $2.43(14)$ \\
\hline Bullock & 1 & 10 & $3.00(49)$ & - & - & - & - & - & - \\
\hline All types & 1 & 30 & $3.84(459)$ & 1 & 29 & $7.64(216)$ & 1 & 9 & $2.67(89)$ \\
\hline
\end{tabular}

\subsection{Natural Disasters Often Affect Cattle Farming}

Natural disasters that frequently affected cattle production at different study areas are shown in Table 3. Irrespective of areas $52.97 \%$ of cattle rearing farmers noticed that occurrence of disaster often affected their cattle production. The highest $62.08 \%$ of farmers thought that cattle rearing affected by flood followed by cyclones (57.83\%). Moreover, cattle rearing farmers also reported that heavy rainfall $(54.00 \%)$, thunderstorms $(44.79 \%)$, drought $(24.07 \%)$, and river erosion $(9.66 \%)$ affecting cattle productions irrespective of the study areas. In the recent past, the weather pattern has been erratic and the alteration of temperature and rainfall patterns has been changed probably attributable to climate change and for this floods, cyclones and seasonal storms increased significantly [18]. From the study, it was revealed that cattle farmers were more affected and vulnerable to floods, cyclones, and heavy rainfall irrespective of the study areas. The previous study reported that floods and cyclones affect directly or indirectly livestock production and result in a direct loss of livestock and indirectly affect livestock by destroying infrastructures [11]. 
Table 3. Natural disasters often affect cattle farming.

\begin{tabular}{|c|c|c|c|c|c|c|c|}
\hline \multirow[b]{2}{*}{ District } & \multicolumn{7}{|c|}{ Cattle farmers opinion over natural disasters } \\
\hline & Farming affected by disaster & Flood & Cyclone & Thunderstorm & $\begin{array}{l}\text { Heavy } \\
\text { rainfall }\end{array}$ & Drought & $\begin{array}{l}\text { River bank } \\
\text { degradation }\end{array}$ \\
\hline Bandarban & $32.00 \%$ & - & $87.50 \%$ & - & - & - & - \\
\hline Chattogram & $77.26 \%$ & $67.91 \%$ & $78.60 \%$ & $59.72 \%$ & $66.51 \%$ & $27.10 \%$ & $4.67 \%$ \\
\hline Jessore & $78.85 \%$ & $55.00 \%$ & - & $2.50 \%$ & $46.15 \%$ & - & - \\
\hline Kurigram & $20.00 \%$ & $25.00 \%$ & - & - & $25.00 \%$ & $62.50 \%$ & - \\
\hline Mymensingh & $45.90 \%$ & $76.00 \%$ & $32.00 \%$ & $60.71 \%$ & $32.00 \%$ & $32.00 \%$ & $52.00 \%$ \\
\hline Sylhet & $19.15 \%$ & $22.22 \%$ & $44.44 \%$ & $33.33 \%$ & $88.89 \%$ & $88.89 \%$ & - \\
\hline Tangail & $21.57 \%$ & - & $66.67 \%$ & $75.00 \%$ & $54.55 \%$ & $36.36 \%$ & - \\
\hline Overall & $52.97 \%$ & $62.08 \%$ & $57.83 \%$ & $44.79 \%$ & $54.00 \%$ & $24.07 \%$ & $9.66 \%$ \\
\hline
\end{tabular}

\subsection{The Strengths of the Ability of the Farmers to Tackle Cattle against Natural Disasters}

The strengths of the ability of the cattle farmers to tackle cattle against natural disasters at different study areas were investigated and shown in Table 4. Irrespective of the areas $43.71 \%$ of cattle farmers reported that they were unable to tackle cattle against natural disasters and the highest $88.89 \%$ of cattle farmers in Sylhet district and followed by Chattogram district (53.44\%) reported they were unable to tackle cattle against natural disasters. Because the cattle houses were mostly made of straw, chatai, mud, tin, and in some cases, tin shed with brick wall and concrete floor which haven't enough strength to protect cattle against cyclones, seasonal storms and floods [19]. Overall $49.40 \%$ of cattle farmers reported that they were somewhat able to tackle their cattle during natural disasters and in Jessore district $100 \%$ of cattle farmers reported they somewhat able to tackle their cattle during natural disasters. Only $6.89 \%$ of farmers reported that they were sufficiently able to tackle their cattle during natural disasters. It was observed that farmers in Sylhet and Chattogram district were more vulnerable to natural disasters and farmers in Jessore, Rajshahi, Bandarban, and Mymensingh districts were moderately vulnerable to natural disasters. From the study, it was also revealed that the farmers in Tangail (44.44\%) district were more capable to tackle their livestock during natural disasters.
Table 4. Strengths of the ability of the farmers to tackle cattle against natural disasters.

\begin{tabular}{llll}
\hline District & Unable & Somewhat able & Sufficiently able \\
\hline Bandarban & $25.00 \%$ & $50.00 \%$ & $25.00 \%$ \\
Chattogram & $53.44 \%$ & $42.86 \%$ & $3.70 \%$ \\
Jessore & - & $100.00 \%$ & - \\
Kurigram & $44.44 \%$ & $33.33 \%$ & $22.22 \%$ \\
Mymensingh & $45.45 \%$ & $36.36 \%$ & $18.18 \%$ \\
Rajshahi & $38.71 \%$ & $61.29 \%$ & - \\
Sylhet & $88.89 \%$ & $11.11 \%$ & - \\
Tangail & $22.22 \%$ & $33.33 \%$ & $44.44 \%$ \\
Overall & $43.71 \%$ & $49.40 \%$ & $6.89 \%$ \\
\hline
\end{tabular}

\subsection{The Farmers' Knowledge and Feelings on the Impact of Climate Change}

The cattle farmers were asked for an opinion about climate change and their feelings on the impact of climate change to examine the knowledge and feelings on climate change at different study areas are shown in Table 5. Irrespective of areas the highest $54.68 \%$ cattle farmers found who had fairly knowledge and feelings on climate change, $21.58 \%$ farmers had much knowledge and feelings, $13.72 \%$ farmers had least knowledge and feelings and $12.95 \%$ farmers were fully ignorant about the impact of climate change. From the study, it was observed that the farmers in Bandarban $(100.00 \%)$, Tangail (66.67\%), Jessore (94.87\%), and Rajshahi (76.19\%) districts were had knowledge and feelings on climate change issues. However, the farmers in Kurigram (97.83\%) and Mymensingh (45.45\%) districts were more ignorant about the climate change issues.

Table 5. Farmers' knowledge and feelings on the impact of climate change.

\begin{tabular}{lllll}
\hline District & Least knowledge and feelings & Much knowledge and feelings & Somewhat knowledge and feelings & No knowledge and feelings \\
\hline Bandarban & - & $100.00 \%$ & - & - \\
Chattogram & $5.45 \%$ & $37.04 \%$ & $37.04 \%$ & $3.70 \%$ \\
Jessore & - & $2.56 \%$ & $94.87 \%$ & $2.56 \%$ \\
Kurigram & $2.17 \%$ & - & - & $97.83 \%$ \\
Mymensingh & $18.64 \%$ & $12.12 \%$ & $27.27 \%$ & $45.45 \%$ \\
Rajshahi & $29.17 \%$ & $19.05 \%$ & $76.19 \%$ & - \\
Sylhet & - & $50.00 \%$ & $50.00 \%$ & - \\
Tangail & $14.29 \%$ & $66.67 \%$ & - & - \\
Overall & $13.72 \%$ & $21.58 \%$ & $54.68 \%$ & $12.95 \%$ \\
\hline
\end{tabular}

\subsection{The Effects of Climate Change on Cattle Rearing Assumed by the Farmers}

The cattle farmers in different study areas opined that climate change had negative impacts on cattle rearing, management, and production. Irrespective of areas the cattle farmers $(64.22 \%)$ assumed that climate change had negative impacts on cattle health. The highest $92.31 \%$ in Jessore district followed by $87.50 \%$ in the Sylhet district, farmers 
assumed that climate change is a cause of ill-health of their cattle. However, farmers assumed that disease prevalence $(36.45 \%)$ of cattle and disease resistance $(19.05 \%)$ increased due to climate change effects. The previous study reported that in the rainy season disease prevalence of cattle generally increases and disease prevalence of cattle in the rainy season is $76.19 \%$ due to marshy environment and poor nutritional status [19]. The replication rate and dissemination of pathogens, vector, and animal host populations are sensitive to changing temperature and rainfall which is related to climate change impact [13]. Moreover, farmers (14.29\%) also assumed that the adaptation of cattle against climate change was a problem in cattle rearing. Adaptation practices such as raising flood-proof houses for cattle, infrastructure for protecting cattle from natural disasters are needed to negotiate the adverse effect of climate change [20]. It was also revealed that $49.09 \%$ of cattle farmers reported about the production of cattle were negatively hampered by climate change effects. Providing comfort to the cattle and protecting from heat stress can improve the production performance of dairy cattle [21]. Moreover, 19.05\% of farmers assumed that the reproduction performance of cattle affected by climate change. Furthermore, behavioral change of cattle was observed by $27.10 \%$ of cattle farmers irrespective of the areas. From the study, it was revealed that cattle health and production performance were mostly affected by climate change issues assumed by the farmers in the study areas.

Table 6. Effects on cattle rearing assumed by the farmers.

\begin{tabular}{|c|c|c|c|c|c|c|c|}
\hline District & Ill-health & Disease prevalence & Disease resistance & Adaptation & Production & Reproduction & Behavioral change \\
\hline Chattogram & $68.00 \%$ & $70.83 \%$ & $62.50 \%$ & $54.17 \%$ & $58.33 \%$ & $54.17 \%$ & $75.00 \%$ \\
\hline Jeshore & $92.31 \%$ & - & - & - & $5.56 \%$ & - & - \\
\hline Mymensingh & $43.75 \%$ & $62.50 \%$ & $31.25 \%$ & $6.25 \%$ & $52.94 \%$ & $18.75 \%$ & $16.67 \%$ \\
\hline Rajshahi & $18.75 \%$ & $5.88 \%$ & - & - & $95.00 \%$ & $6.25 \%$ & - \\
\hline Sylhet & $87.50 \%$ & $62.50 \%$ & - & $12.50 \%$ & $75.00 \%$ & $37.50 \%$ & $100.00 \%$ \\
\hline Tangail & - & $100.00 \%$ & - & - & $80.00 \%$ & - & - \\
\hline Overall & $64.22 \%$ & $36.45 \%$ & $19.05 \%$ & $14.29 \%$ & $49.09 \%$ & $19.05 \%$ & $27.10 \%$ \\
\hline
\end{tabular}

\section{Conclusions}

Climate change and natural disasters have multidimensional effects on humans, animals, environment, and these issues are now a worldwide concern. The geographical location of Bangladesh makes it the most vulnerable country in the world considering climate change issues. This study revealed the cattle farmers' perspective of cattle rearing considering natural disasters and climate change issues. Cattle rearing in Bangladesh directly and indirectly affected by natural disasters and changes in climate patterns due to climate change effect. From the study it was concluded that most of the households $(95.13 \%)$ were farm households depending on agricultural activities irrespective of the study areas. The average number of bull calf/bull in the case of indigenous and RCC were higher because farmers were mainly reared these genotypes of cattle for fattening purpose and in the case of crossbred the average number of the milch cow was higher reason behind that farmers reared crossbred cattle mainly for dairy purpose. The cattle herd size of indigenous, crossbred, and RCC was found 3.84, 7.64, and 2.67 respectively. The cattle farmers were found vulnerable and affected by floods, cyclones, and heavy rainfall irrespective of the study areas. However, $43.71 \%$ of cattle farmers reported that they were unable to tackle cattle against natural disasters. The farmers in Bandarban, Tangail, Jessore, and Rajshahi districts were had more knowledge and feelings on climate change issues and the farmers in Kurigram and Mymensingh districts were more ignorant about climate change issues. Mostly, the cattle health and production performance were affected by climate change assumed by the farmers found in the study areas. However, for the maximum use of the potentiality of the livestock sector in the changed climatic conditions more specific and in-depth research is needed to conduct in Bangladesh. This research will help as the preliminary base for further research and policymakers to give more emphasis on cattle farming as well as the livestock sector for achieving maximum productivity considering climate change issues in Bangladesh perspective.

\section{Ethical Approval}

This article does not contain any studies performed on animals.

\section{Conflict of Interest}

The authors declare that they have no conflict of interest.

\section{Acknowledgements}

This research was funded by the research project of "Conservation and Improvement of Red Chittagong Cattle, $2^{\text {nd }}$ Phase", Bangladesh Livestock Research Institute, Dhaka, Bangladesh.

\section{References}

[1] Rahman M. S. (2013). Climate Change, Disaster and Gender Vulnerability: A Study on Two Divisions of Bangladesh. American Journal of Human Ecology. 2 (2): 72-82.

[2] Eckstein D., Hutfils M. L., and Winges M. (2018). Global Climate Risk Index 2019. Bonn, Germany: German watch eV. https://www.germanwatch.org/en/cri. 
[3] IPCC (Intergovernmental Panel on Climate Change) (2001). Climate Change: The scientific basis, New York: Cambridge University Press.

[4] Faroque M. A. A., Asaduzamman M., Hossain M. (2013). Sustainable Agricultural Development under Climate Change in Bangladesh. J Sci Found. 11 (1): 17-28.

[5] Basak J. K., Titumir R. A. M. and Dey N. C. (2013). Climate Change in Bangladesh: A Historical Analysis of Temperature and Rainfall Data Journal of Environment. 2 (2): 41-46 https://www.scientific-journals.co.uk.

[6] Hossain M. S., Qian L., Arshad L., Shahid S., Fahad S., Akhter J. (2019). Climate change and crop farmingin Bangladesh: an analysis ofeconomic impacts. International Journal of Climate Change Strategies and Management. 11 (3): 424-440, https://doi:10.1108/IJCCSM-04-2018-0030.

[7] Charlotte S. (2011). Review of Climate Change Adaptation Practices in South Asia. Oxfam Res. Reports. http://www.oxfam.org/sites/www.oxfam.org/files/rr-climatechange-adaptation-south-asia-161111-en.pdf.

[8] Alam M. Z., Carpenter-Boggs L., Mitra S., Haque M. M., Halsey J., Rokonuzzaman M., Saha B., and Moniruzzaman M. (2017). Effect of Salinity Intrusion on Food Crops, Livestock, and Fish Species at Kalapara Coastal Belt in Bangladesh. Journal of Food QualityVolume, Article ID 2045157, 23 pages. https://doi.org/10.1155/2017/2045157.

[9] Huq N., Hugé J., Boon E. and Gain A. K. (2015). Climate Change Impacts in Agricultural Communities in Rural Areas of Coastal Bangladesh: A Tale of Many Stories. Sustainability. 7, 8437-8460; https://doi:10.3390/su7078437.

[10] IPCC (Intergovernmental Panel on Climate Change) (2014). Climate change 2014. Fifth Assessment Synthesis Report. Intergovernmental Panel on Climate Change. Geneva.

[11] Musemwa L., Muchenje V., Mushunje A. and Zhou L. (2012). The Impact of Climate Change on Livestock Production amongst the Resource-Poor Farmers of Third World Countries: A Review, Asian Journal of Agriculture and Rural Development, 2 (4): 621-631.

[12] Van den Bossche P. and Coetzer J. A. W. (2008). Climate Change and Animal Health in Africa Review Science Technology Off.int. Epiz. 27 (2): 551-562.
[13] Kimaro E. G., and Chibinga O. C. (2013). Potential Impact of Climate Change on Livestock Production and Health in East Africa: A Review. Livestock Research for Rural Development 25 (7): 1-11.

[14] Gardner I. (2012). Strengthening Tanzanian Livestock Health and Pastoral Livelihoods in a Changing Climate, Research Briefs.

http://lcccrsp.org/wpcontent/uploads/2012/03/Gardner_RB_07 _2012.pdf.

[15] ARSS (Agriculture and Rural Statistics Survey) (2018). Bangladesh Bureau of Statistics, Statistics and informatics division, Ministry of planning, Government of the peoples' republic of Bangladesh. Chapter 3, 19-30 bbs.portal.gov.bd.

[16] Quddus M. A. and Amin M. R. (2010). Constraints of Native Cattle Genetic Resource Conservation and Features of Breeding System in Representative Areas of Bangladesh. J. Bangladesh Agril. Univ. 8 (1): 113-120.

[17] Quddus M. A. (2017). Performance and Perceptions of Adoption of Crossbred Cattle by Smallholder in Bangladesh. International Journal of Agricultural Policy and Research. 5 (3): 63-69. https://doi.org/10.15739/IJAPR.17.007.

[18] Sikder R. and Xiaoying J. (2014). Climate Change Impact and Agriculture of Bangladesh. Journal of Environment and Earth Science. 4 (1): 35-40.

[19] Simul A. I., Bhuiyan A. K. F. H., Alam M. K., Sarkar M. M. and Rahman M. M. (2012). Feeding and Management Practices of Red Chittagong Cattle in Two Selected Upazilas of Chittagong District. Bang. J. Anim. Sci. 41 (1): 35-40.

[20] Sutradhar L. C., Bala S. K., Islam A. K. M. S., Hasan M. A., Paul S., Rhaman M. M, Pavel M. A. A. and Billah M. (2015). A Review of Good Adaptation Practices on Climate Change in Bangladesh. $5^{\text {th }}$ International Conference on Water \& Flood Management (ICWFM-2015). 607-614.

[21] Younas M., Ishaq K., Ali I. (2012). Effect of Climate Change on Livestock Production in Pakistan. Proceeding of the 2nd International Seminar on Animal Industry. Jakarta, 5-6 https://www.researchgate.net/publication/236133490. 